\title{
EXTRA SKELETAL EWING'S SARCOMA PRESENTED WITH FOCAL SEIZURE AND \\ HEMORRHAGIC STROKE-LIKE TABLE: A CASE REPORT
}

\author{
Erman ALTUNIŞIK1ํ, Ali Zeynal Abidin TAK¹, Yaşar ALTUN¹, Ali Haydar BAYKAN² \\ ${ }^{1}$ Adıyaman University Faculty of Medicine, Department of Neurology, Adıyaman, TÜRKIYE \\ ${ }^{2}$ Adıyaman University Faculty of Medicine, Department of Radiology, Adıyaman, TÜRKIYE
}

\begin{abstract}
Extra skeletal Ewing's sarcoma (EES) is a rare tumor originating from non-bone tissues and consisting of small round cells with a fragment or lobular distribution. What is known about the central nervous system (CNS) metastases of EES is extremely limited. Our case, which was not diagnosed before and initially presented with neurological symptoms and CNS involvement, is the first case in the literature. We aimed to contribute to the literature through this case. A 26-year-old male patient was admitted to the emergency department with sudden headache, weakness on the right side and involuntary fast clonic contractions localized in the right arm and leg. Computed tomography (CT) revealed hemorrhagic appearance in the left frontoparietal region, upon which the patient was hospitalized with a preliminary diagnosis of hemorrhagic stroke. The patient had complete clinical recovery and his focal seizure was under control. After two weeks, the patient presented to the emergency department again with a complaint of headache. CT revealed hemorrhageconsistent appearance in the right parietal region. Mass lesions accompanied by edema sites and intravenous contrast enhancement were detected around hemorrhagic lesions in both hemispheres in magnetic resonance imaging (MRI). In the following days MRI examination of the left leg was performed due to pain and swelling in the left thigh. A mass lesion was detected in the left thigh. The patient was diagnosed with ES as a result of the histopathological examination and evaluated as having EES. Neurological findings can be seen in many malignant diseases as a result of both solid involvement and paraneoplastic processes. It should be kept in mind that even in patients who have not yet been diagnosed, neurological findings can be observed, which can facilitate the primary diagnosis.
\end{abstract}

Keywords: Ewing's sarcoma, Extraskeletal Ewing's sarcoma, computed tomography, seizure, hemorrhagic stroke, metastasis.

\footnotetext{
Address for Correspondence: Erman Altunışık, MD. Adıyaman University Faculty of Medicine, Department of Neurology, Adıyaman, Türkiye. Phone: +904162161015 E-mail: ermanaltunisik@gmail.com Received: $28.12 .2020 \quad$ Accepted: 19.02 .2021

ORCID IDs: Erman Altunıșık 0000-0002-5996-2090, Ali Zeynel Abidin Tak 0000-0002-3783-184X, Yașar Altun 0000-0001-7013-0618, Ali Haydar Baykan 0000-0002-9281-652X.

Please cite this article in press as: Altunıșık E, Tak AZA, Altun Y, Baykan AH. Extra Skeletal Ewing's Sarcoma presented with focal seizure and hemorrhagic stroke-like table: a case report. Turkish Journal of Cerebrovascular Diseases 2022; 28(2): 123-127. doi: 10.5505/tbdhd.2021.32704
} 


\title{
FOKAL NÖBET VE HEMORAJÍK STROK BENZERİ TABLO İLE PREZENTE OLAN
}

\author{
EXTRA SKELETAL EWING SARKOMU: OLGU SUNUMU
}

\section{öz}

Ekstra skeletal Ewing sarkomu (EES), kemik dışı dokulardan kaynaklanan, fragman veya lobüler dağılım gösteren küçük yuvarlak hücrelerden oluşan nadir bir tümördür. EES'nin santral sinir sistemi (SSS) metastazları hakkında bilinenler son derece sınırlıdır. Daha önce tanı konulmayan ve başlangıçta nörolojik semptomlar ve SSS tutulumu ile prezente olan olgumuz literatürdeki ilk olgudur. Bu vaka ile literatüre katkı sağlamayı amaçladık. 26 yaşında erkek hasta ani baş ağrısı, sağ tarafta güçsüzlük ve sağ kol ve bacakta lokalize olan istem dişı hızlı klonik kasılmalar ile acil servise başvurdu. Bilgisayarlı tomografide (BT) sol frontoparietal bölgede hemorajik görünüm izlendi ve hasta hemorajik inme ön tanısıyla interne edildi. Hasta klinik olarak tamamen düzeldi ve fokal nöbeti kontrol altına alındı. İki hafta sonra hasta baş ağrısı yakınması ile tekrar acil servise başvurdu. BT'de sağ parietal bölgede kanamayla uyumlu bir görünüm saptandı. Manyetik rezonans görüntülemede (MRG) her iki hemisferde hemorajik lezyon çevresinde ödem bölgelerinin eşlik ettiği kitle lezyonları ve periferik kontrastlanma tespit edildi. Sonraki günlerde sol uylukta ağrı ve şişlik nedeniyle sol femur MRG incelemesi yapıldı. Sol uylukta kitlesel lezyon tespit edildi. Hastaya histopatolojik inceleme sonucunda ES tanısı kondu ve EES olarak değerlendirildi. Hem solid tutulum hem de paraneoplastik süreçler sonucunda birçok malign hastalıkta nörolojik bulgular görülebilmektedir. Henüz tanı konmamış hastalarda dahi nörolojik bulguların görülebildiği ve bu da birincil tanıyı kolaylaştırabileceği akılda tutulmalıdır.

Anahtar Sözcükler: Ewing's sarkom, Extra skeletal Ewing sarkom, bilgisayarlı tomografi, nöbet, hemorajik stroke, metastaz.

\section{INTRODUCTION}

Ewing's sarcoma (ES) is a primary malignant bone tumor and primary locations are the femur, pelvis, humerus and tibia. Lungs and bones are the most commonly locations of metastasis. The incidence of metastatic disease is high in many patients at the time of diagnosis (1). The ES tumor family refers to a wide spectrum of neoplastic diseases that can develop in any bone or soft tissue, including ES, extraskeletal variants, primitive neuroectodermal tumor and Askin's tumor, and neoplasms that belong to this family are known to have histopathologically similar findings (2). Extra skeletal Ewing's sarcoma (EES) is a rare tumor seen in this family originating from non-bone tissues and consisting of small round cells with a fragment or lobular distribution. EES accounts for $1.1 \%$ of soft tissue tumors and is frequently seen in young men aged 15 to 30 , often originating from the paravertebral, lower limb and chest wall, but rarely occurring in the upper limb, neck and retroperitoneal area (3).

The central nervous system (CNS) metastases of ES are very rare. The main symptoms of CNS involvement have been reported as headache, papillary edema, diplopia and paresis. As the lifespan of these patients has increased, the incidence of neurological complications has also increased (1). Intracranial involvement is generally seen in advanced cases and known to originate from the skull base and calvarium $(4,5)$. Furthermore, what is known about the CNS metastases of EES is extremely limited. Our case, which was not diagnosed before and initially presented with neurological symptoms and CNS involvement, is the first case in the literature. This clinical condition, which was not reported previously in the literature was found worth presenting. We aimed to contribute to the literature through this case.

\section{CASE REPORT}

A 26-year-old male patient was admitted to the emergency department with sudden headache, weakness on the right side and involuntary fast clonic contractions localized in the right arm and leg. There was no remarkable feature in his past medical history or that of his family. Upon neurological examination, he was found to be conscious and cooperative, and had complete orientation. The right side muscle strength was measured as $4 / 5$. There was no cranial nerve pathology. His fundus examination was normal and neck stiffness was not detected. Deep tendon reflexes were normoactive, and the foot skin reflex gave bilateral flexor response. The sensory examination revealed right hemihypoesthesia. There was no fever and other vital parameters 
were within normal limits. Cranial computed tomography (CT) revealed hemorrhagic appearance in the left frontoparietal region (Figure 1a), upon which the patient was hospitalized with a preliminary diagnosis of hemorrhagic stroke. Blood biochemistry, hemogram and inflammatory markers were within normal limits. The patient was started levetirecetam and mannitol treatment. During the follow-up, his seizures were taken under control, and his paresis improved. CT angiography was performed for vascular etiology and no aneurysm, arteriovenous malformation or a different vascular pathology was observed. Autoimmune and vasculitis panel studies were within normal limits. There were no laboratory findings suggesting bleeding diathesis. No pathological wave was observed in electroencephalography. The patient had complete clinical recovery and his focal seizure was under control; thus, he was discharged from the hospital to be followed-up on an outpatient basis. After two weeks, the patient presented to the emergency department again with a complaint of headache. His neurological examination findings were within normal limits. However, CT revealed hemorrhage-consistent appearance in the right parietal region (Figure 1b), and the patient was again hospitalized. The contrast-enhanced magnetic resonance imaging (MRI) of the brain was performed to investigate the nature of hemorrhagic lesions. Mass lesions accompanied by edema sites were detected around hemorrhagic lesions in both hemispheres (Figure 1c-1d). A peripheral contrast involvement pattern was observed. Both lesions were evaluated in favor of metastasis. A CT of the upper and lower abdomen and thorax was taken for the screening of the primary disease. No pathology was detected on the abdominal CT but nodular densities were evaluated indicating metastasis of both lungs. No significant finding was noted in tumor markers. In the following days of hospitalization, an MRI examination of the right leg was performed due to pain and swelling in the left thigh. A mass lesion with a diameter of $6 \mathrm{~cm}$ that did not impair the structural integrity of bone cortex was detected in the left thigh (Figure 2a-2b). The patient was diagnosed with ES with the histopathological examination and evaluated as having EES, since the integrity of the bone structure was not disrupted. The primary origin was successfully identified, and diffuse metastatic involvements were detected; thus, there was no need for histopathological sampling from the intracranial lesions. He was referred to the oncology department for treatment. Of note, informed consent was signed by the patient regarding this case report.

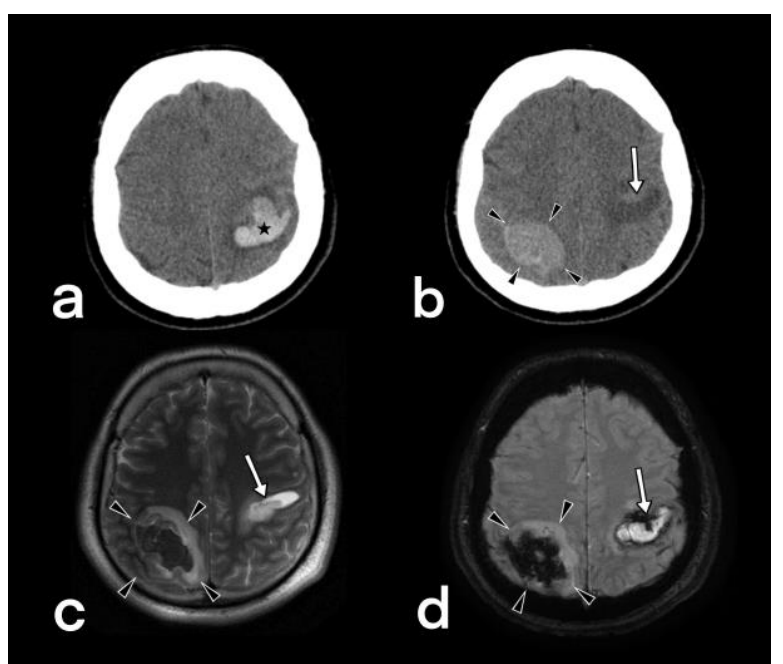

Figure 1. Cranial axial CT and T2 weighted axial and SWAN MRI examination of the patient. Cranial axial CT examination of the patient performed at the time of his presentation to the emergency department (a). On the left, the bleeding area (asterisk) is observed as hyperdense in the frontoparietal region. The cranial CT of the patients after 15 days(b), T2 weighted axial MRI (c) and SWAN MRI (d) examination show a new bleeding area (arrowheads) in the parietal region on the right. The bleeding area is hyperdense on CT and has mixed intensity on MRI. The initial bleeding area is indicated by an arrow. ${ }^{*} \mathrm{CT}$ : Computed tomography, MRI: Magnetic resonance imaging, SWAN: Susceptibility-weighted angiography MRI.

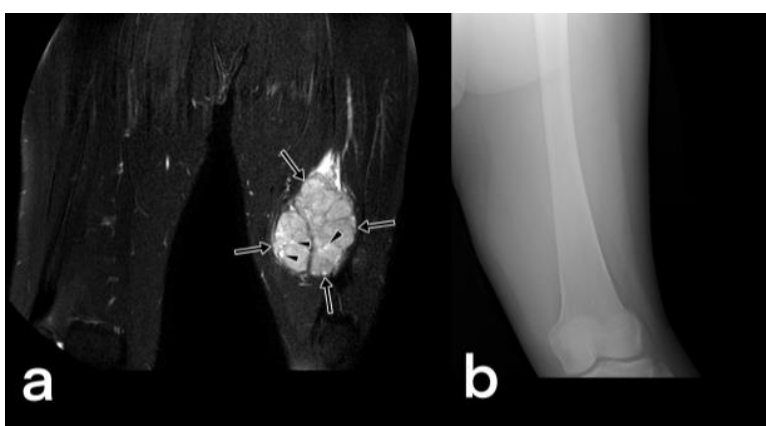

Figure 2. T2-weighted fat-suppressed MRI and X-Ray image of left thigh. In T2-weighted fat-suppressed MRI (a), a well-defined mass of approximately $6 \mathrm{~cm}$ in diameter is observed in the soft tissue on the left thigh (arrows). Areas with higher signals (arrowheads) represent small bleeding areas within the mass. Note that the bone structure is preserved in the X-Ray image taken simultaneously (b), and there is no irregularity in the bone cortex. Extra-skeletal Ewing's sarcoma can be very aggressive and metastatic without damaging the integrity of the bone structure (except in advanced stages). *MRI: Magnetic resonance imaging. 


\section{DISCUSSION AND CONCLUSION}

Information about the CNS metastases of EES is extremely limited and there are only rare cases reported in the literature. The source of our information on this subject is ES, which originates mostly from bone structure. The similarities of ES and EES in terms of histopathology, clinical findings and prognosis made it necessary to discuss the current case considering what is known about ES.

Metastasis of ES to CNS is extremely rare and is almost always associated with disseminated disease, which can also be detected in other organs (6). In CNS metastases, parenchymal involvement is even rarer. In a study in which 134 patients with ES were reviewed, only three (2.2\%) showed evidence of parenchymal brain metastasis and in all three, diffuse metastases in other body regions were known before the metastases of the parenchymal brain. CNS involvement most often occurs because of direct expansive extension from the skull or vertebral bone lesions, and primary parenchymal brain metastasis is extremely rare (7). ES has two reported forms of metastatic spread. The first is the direct expansion of the primary or secondary ES from the skull, and the other is the hematogenous route (8). The first route of spread is seen more frequently (1). In our case, we considered the possible spread route as a rare hematogenous route since the patient's CNS lesions were detected only in the parenchyma with no metastatic involvement of the dura, calvarium or head bones.

In the literature, there are very few cases with CNS involvement secondary to ES metastasis that subsequently developed seizures, and this was seen to be accompanied by parenchymal involvement (9). We did not encounter a case experiencing seizures after EES metastasis. In our case, the presence of seizures emerged as one of the first clinical findings both before the diagnosis of the primary disease and prior to the detection of intracranial lesions. No factor that could affect the seizure threshold was observed in our patient.

There are also some cases complicated by spontaneous intraneoplastic hemorrhage in patients with intraparenchymal metastasis (10). Cases experiencing seizures and intraneoplastic hemorrhage during the course of the disease have also been reported (11). These cases have similar features to our case in terms of seizure-consistent clinical findings and the detection of spontaneous intraneoplastic hemorrhage on imaging, but the difference is that in previous cases, the primary disease had been diagnosed and the presence of CNS metastases was known before the clinical manifestation. At the time of the first presentation of our case, the patient was hospitalized with a preliminary diagnosis of hemorrhagic stroke, and the CT images taken were interpreted in favor of intracranial hemorrhage by radiologists. Thus, our study focusing on a clinical situation that can easily be overlooked emphasizes that the possibility of intracranial space-occupying lesions should be taken into consideration in the differential diagnosis of hemorrhagic stroke.

Only publications on the cranial parenchymal metastases of EES are in the form of case reports (12). In the literature, we did not see any case in which the CNS involvement of EES or ES was reported at the time of presentation. There was also no reported case presenting with neurological symptoms and signs. Therefore, the case we present in this paper has the characteristic of being the first and only case in the literature in terms of both clinical and radiological features. Neurological findings can be seen in many malignant diseases because of both solid involvement and paraneoplastic processes. The brain can be the target of many primary malignant neoplasms. All oncological patients treated should be alerted to neurological symptoms, and neuroimaging should not be avoided. It should be kept in mind that even in patients who have not yet been diagnosed, neurological findings can be observed, which can facilitate the primary diagnosis. This should be taken into consideration even in malignancies where neurological involvement is very rare, as in our case.

\section{REFERENCES}

1. Mehta Y, Hendrickson FR. CNS involvement in Ewing's sarcoma. Cancer 1974; 33(3): 859-862.

2. Murphey MD, Senchak LT, Mambalam PK, et al. From the radiologic pathology archives: Ewing sarcoma family of tumors: Radiologic-Pathologic Correlation 2013; 33(3): 803-831.

3. Xie CF, Liu MZ, Xi M. Extraskeletal Ewing's sarcoma: a report of 18 cases and literature review. Chin J Cancer 2010; 29(4): 420-424.

4. Elias B, Uhl E. Intra and parasellar manifestation of an Ewing's sarcoma before detection of the primary tumour. 
Acta Neurochir 2002; 144(7): 747-748.

5. Navarro R, Laguna A, Torres C, et al. Primary Ewing sarcoma of the tentorium presenting with intracranial hemorrhage in a child. J Neurosurg 2007; 107(5): 411-415.

6. Trigg ME, Glaubiger D, Nesbit ME Jr. The frequency of isolated CNS involvement in Ewing's sarcoma. Cancer 1982; 49: 2404-2409.

7. Dams R, Park H, Alomari A, et al. Adjuvant hypofractionated partial-brain radiation therapy for pediatric Ewing sarcoma brain metastases: case report. J Neurosurg Pediatr 2016; 17(4): 434-438.

8. Li WY, Brock P, Saunders DE. Imaging characteristics of primary cranial Ewing sarcoma. Pediatr Radiol 2005; 35(6): 612- 618.

9. Shuper A, Cohen IJ, Mor C, et al. Metastatic brain involvement in Ewing family of tumors in children. Neurology 1998; 51(5): 1336-1338.

10. Olivi A, Ross CD, Mann RB, et al. Solitary, isolated metastasis from Ewing's sarcoma to the brain: case report. Surg Neurol 1991; 35(3): 239-43.
11. Capitini CM, Derdak J, Hughes MS et al. Unusual sites of extraskeletal metastases of Ewing sarcoma after allogeneic hematopoietic stem cell transplantation. J Pediatr Hematol Oncol 2009; 31(2): 142-144.

12. Bindal R, Sawaya RE, Leavens ME, et al. Sarcoma metastatic to the brain: results of surgical treatment clinical study. Neurosurgery 1994; 35(2): 185-191.

Ethics

Informed Consent: The authors declared that informed consent form was signed by the patient.

Copyright Transfer Form: Copyright Transfer Form was signed by the authors.

Peer-review: Internally peer-reviewed.

Authorship Contributions: Surgical and Medical Practices: EA, AZAT, YA, AHB. Concept: EA, AZAT, YA, AHB. Design: EA, AZAT, YA, AHB. Data Collection or Processing: EA, AZAT, YA, AHB. Analysis or Interpretation: EA, AZAT, YA, AHB. Literature Search: EA, AZAT, YA, AHB. Writing: EA, AZAT, YA, AHB.

Conflict of Interest: No conflict of interest was declared by the authors.

Financial Disclosure: The authors declared that this study received no financial support. 